\title{
Assessing long term trends of air pollutants and associated health risks imposed on residents in Bolu (Turkey) during winter
}

\author{
Fatma Öztürk a, Melek Keleş Özgül b
}

\begin{abstract}
a Assoc. Prof., Bolu Abant İzzet Baysal University, Faculty of Engineering, Environmental Engineering Department, Gölköy, Bolu, Turkey

b PhD Student., Bolu Abant İzzet Baysal University, Faculty of Engineering, Environmental Engineering Department, Gölköy, Bolu, Turkey
\end{abstract}

Submitted date: 26.05.2018, Accepted date: 19.06.2019

\begin{abstract}
Objective: The objective of this study was to evaluate the long term and seasonal variation of $\mathrm{PM}_{10}$ and $\mathrm{SO}_{2}$ in the the Bolu city center between 2006 and 2017 in relation to meteorological parameters and to evaluate the health risks due to metals bound to particulate matter (PM) during the winter season. Method: The Seasonal Kendall (SK) test was performed on the air quality data to find the magnitude of associated trends. In addition, seasonality of these pollutants was evaluated in conjunction with the meteorological parameters. Furthermore, daily PM samples in two different size fractions were collected between December 2014 and February 2015 and analyzed for metals by WDXRF. The generated metal concentrations were used to estimate carcinogenic and noncarcinogenic health risks imposed on the residents of the city. Results: The SK test revealed statistically significant decline in $\mathrm{SO}_{2}$ and $\mathrm{PM}_{10}$ with a rate of 1.953 and $2.932 \mu \mathrm{g} / \mathrm{m}^{3} / \mathrm{year}$, respectively, at $5 \%$ significance level. Both of the parameters depicted very clear seasonal cycles. Performed exposure risk assessment indicated that dermal contact with PM bound metals was the main route of exposure for children, while the adults were more prone to non-carcinogenic risks from exposure through inhalation. Conclusion: Overall, children were found to be more susceptible to non-carcinogenic risks as compared to adults. The cancer risks due to $\mathrm{As}$ and $\mathrm{Pb}$ were within the acceptable limits $\left(<1 \times 10^{-4}\right)$.
\end{abstract}

Key words: Bolu, Particulate Matter, Sulfur Dioxide, Air Pollution, Risk Assessment

Corresponding Author: Fatma Öztürk, Abant İzzet Baysal University Faculty of Engineering and Architecture, Environmental Engineering Department, Gölköy, Bolu, Turkey, 14030 E-mail: ozturk fatma@ibu.edu.tr

Copyright holder Turkish Journal of Public Health

This work is licensed under a Creative Commons Attribution-NonCommercial 4.0 International License. (c) EY-No This is an open Access article which can be used if cited properly. 


\section{Bolu atmosferinde gözlenen kirleticilerin uzun dönem değişimlerinin ve kış mevsiminde şehirde yaşayan halk üzerinde sebep olduğu maruziyet riskinin değerlendirmesi}

Özet

Amaç: $\mathrm{Bu}$ çalışmanın amacı hava kalitesini belirleyen iki önemli kirletici olan $\mathrm{PM}_{10}$ ve $\mathrm{SO}_{2}$ seviyelerinin Bolu şehir merkezinde 2006 ve 2017 yılları arasındaki uzun dönem ve mevsimsel değişimlerini meteorolojik parametreleri dikkate alarak incelemek ve kış mevsiminde toplanan PM örneklerinde belirlenen metallerden kaynaklanan sağlık riskinin belirlenmesidir. Yöntem: Bolu şehir merkezinde izlenen $\mathrm{SO}_{2}$ ve $\mathrm{PM}_{10}$ seviyelerinde istatistiksel açıdan anlamlı bir azalma olup olmadığı ve azalma oranı Seasonal Kendall (SK) testi kullanılarak belirlenmiştir. Bununla birlikte bu iki kirleticinin mevsimsel değișim göstermedikleri meteorolojik parametrelerle ilişkileri dikkate alınarak incelenmiștir. Aralık 2014-Şubat 2015 tarihleri arasında iki farklı dane boyutunda toplanan PM örnekleri WDXRF cihazı kullanarak metal içeriklerinin belirlenmesi açısından analiz edilmiştir. Üretilen metal konsantrasyonları şehirde yaşayan halkın maruz kaldığı kanserojen olan ve olmayan sağlık risklerinin hesaplanmasında kullanılmıştır. Bulgular: Veri setine uygulanan SK testi ile \%5 anlam seviyesinde $\mathrm{SO}_{2}$ için bu dönemde azalma oranı $1.953 \mu \mathrm{g} / \mathrm{m}^{3} / \mathrm{yll}, \mathrm{PM}_{10}$ için ise $2.932 \mu \mathrm{g} / \mathrm{m}^{3} / \mathrm{yll}$ olarak bulunmuştur. Her iki parametre de bu dönemde çok belirgin mevsimsel değişim göstermiştir. Üretilen veri seti ile yapılan maruziyet riski değerlendirmesi ile çocuklar için cilt temasının erişkinler için ise solunumun partikül maddeye bağlı metallerin insan vücuduna geçmesinde ana yol olduğu bulunmuştur. Sonuç: Genel olarak, çocukların kanserojen olmayan risklere yetişkinlere kıyasla daha hassas oldukları belirlenmiştir. Çalışma kapsamında değerlendirilen metallerden $\mathrm{As}$ ve $\mathrm{Pb}$ için hesaplanan kanser riskinin kabul edilebilir $\left(<1 \times 10^{-4}\right)$ değerin altında olduğu saptanmıștır.

Anahtar kelimeler: Bolu, Partikül Madde, Kükürt Dioksit, Hava Kirliliği, Risk Değerlendirmesi

\section{Introduction}

Air pollution is recognized as one of the main environmental problems that release miscellaneous pollutants into the atmosphere that cause harm to humans, other living organisms and the environment. ${ }^{1}$ Among the various air pollutants, particulate matter (PM) with varying size and chemical composition is of major concern both in developed and developing countries due to its ubiquitous nature.

PM is introduced into the atmosphere as primary and secondary particles. The former includes the particles released directly from their source, mainly by combustion whilst secondary particles are formed in the 
atmosphere because of chemical reactions of compounds with low volatility. The comportment of particles within the atmosphere and human respiratory system is partly determined by their physical properties such as size. A simple difference is that particles of less than about $2.5 \mu \mathrm{m}$ can penetrate deep into the respiratory system towards alveoli and terminal bronchioles while larger particles with a size up to $10 \mu \mathrm{m}$ deposit predominantly in the primary bronchi. ${ }^{2} \mathrm{PM}$ with aerodynamic size less than $2.5 \mu \mathrm{m}\left(\mathrm{PM}_{2.5}\right)$ is recognized as fine and one with particle size between 2.5 and $10 \mu \mathrm{m}$ $\left(\mathrm{PM}_{2.5-10}\right)$ forms the coarse mode.

Various epidemiological studies have reported relationships between long-term exposure to $\mathrm{PM}_{2.5}$ mass concentration and increased mortality in urban populations. ${ }^{3}$ World Health Organization (WHO) estimates that approximately 3 million people die globally each year due to exposure to ambient air pollution, implying that air pollution is one of the world's leading environmental problem.4,5 Evans et al. revealed that globally $9.4 \%$ of ischemic heart disease (IHD) is because of the $\mathrm{PM}_{2.5}$ exposure. ${ }^{6}$ Numerous studies have shown that there is increasing evidence of the impacts of PM on cardiovascular disease (CD) and respiratory disease (RD). ${ }^{7-10}$ Results by Pascal et al. confirmed that both $\mathrm{PM}_{2.5}$ and $\mathrm{PM}_{10-2.5}$ have short-term impact on mortality. ${ }^{11}$

The chemical composition of PM also determines its toxicity. Especially, the metal content of $\mathrm{PM}_{2.5}$ is exerting detrimental impacts on human health. Metallic component of PM is produced from a variety of sources including metallurgical processes and exhaust (from impurities of fuel additives) and nonexhaust emissions (from brake abrasion, spare parts of the automobiles). ${ }^{2}$

Metals play a role as possible mediators of PM prompted airway harm and inflammation through the Fenton reaction. ${ }^{12-14}$ Burnett et al. reported a strong association between $\mathrm{Fe}, \mathrm{Ni}$, $\mathrm{Zn}$ as well as sulfate within fine and Sc, Mn, Ni and Zn within coarse mode of
PM and short-term mortality. ${ }^{15}$ Moreover, Ostro et al. revealed correlation with $\mathrm{Ca}, \mathrm{Fe}$, $\mathrm{Cu}, \mathrm{Mn}, \mathrm{Ti}, \mathrm{Zn}$ and sulfate, present in $\mathrm{PM}$, and short-term mortality. ${ }^{16}$ Furthermore, it has been found out that the elevated ambient levels of $\mathrm{Ni}$ and $\mathrm{V}$ caused increased wheeze in two year old children. ${ }^{17}$ An association between short term impacts of $\mathrm{PM}_{2.5}$ on cardiovascular and respiratory hospitalizations and ambient levels of $\mathrm{V}, \mathrm{Ni}$, and elemental carbon (EC) was determined in $\mathrm{PM}_{2.5}$ samples. ${ }^{18}$ In addition, Hirshon et al. showed a correlation between the previous day $\mathrm{PM}_{2.5} \mathrm{Zn}$ levels and risk of pediatric asthma exacerbations. ${ }^{19}$

Furthermore, $\mathrm{As}, \mathrm{Ni}, \mathrm{Cd}$ and $\mathrm{Cr}$ are classified as Class I carcinogenic contaminants by the International Agency for Research on Cancer (IARC). People exposed to As upon inhalation are at an excess risk of lung cancer. ${ }^{20}$ Airborne $\mathrm{Cd}$ mass concentration is associated with chronic renal failure. ${ }^{21}$ The IARC classify $\mathrm{Pb}$ as Class II(B) carcinogen, i.e., possible human carcinogen. Elevated parental $\mathrm{Pb}$ exposure leads to the risk of spontaneous abortion and reduced fetal growth. ${ }^{22} \mathrm{Zinc}, \mathrm{Cu}$ and $\mathrm{Mn}$ have been classified as noncarcinogenic contaminants. On the other hand, Shao et al. showed that $\mathrm{Zn}$ associated with $\mathrm{PM}_{2.5}$ results in damage to DNA plasmid. ${ }^{23}$

The gaseous atmospheric pollutants at elevated concentrations have significant adverse impacts on human health and environment. For example, sulfur dioxide $\left(\mathrm{SO}_{2}\right)$ can be converted to sulfuric acid in the atmosphere, which leads to the damage of lungs and various lung disorders including wheezing and shortness of breath. ${ }^{24}$ Moreover, $\mathrm{SO}_{2}$ results in eye irritation, asthma attacks, cardiopulmonary diseases and increase of mortality rates. ${ }^{25}$ Kesic et al. also reported that $\mathrm{SO}_{2}$ can cause amplification of viral infections. ${ }^{26}$

Turkish Ministry of Environment and Urbanization has been operating an air quality monitoring station at the Bolu city center since 2006. Only, $\mathrm{PM}_{10}$ and $\mathrm{SO}_{2}$ have been routinely monitored at this station. Unfortunately, there 
is yet no literature on the status of air quality for the city in terms of these two pollutants. On the other hand, Öztürk and Keleş reported the chemical composition of PM in terms of metals and carbonaceous material for Bolu city center. ${ }^{27}$

The objectives of this study are twofold: (1) To evaluate the long term and seasonal variation of two criteria pollutants (namely, $\mathrm{PM}_{10}$ and $\mathrm{SO}_{2}$ ) and their relation with the meteorological parameters. (2) To address the health risks associated with the heavy metal content of $\mathrm{PM}_{2.5-10}$ and $\mathrm{PM}_{2.5}$ samples, which were collected under very stable atmospheric conditions during winter in Bolu.

\section{Method}

Sample Collection and Analysis
A Gent-type stack filter unit (SFU) having polycarbonate (Nuclepore) filters in series were used to collect daily coarse $\left(\mathrm{PM}_{2.5-10}\right)$ and fine $\left(\mathrm{PM}_{2.5}\right)$ samples between 1 December 2014 and 6 February 2015 at the center of Bolu, Turkey (Figure 1). Details of collection and analysis of samples were provided in Öztürk and Keleș. ${ }^{27}$ Briefly, filters were conditioned at constant temperature $\left(20^{\circ} \mathrm{C}\right)$ and relative humidity (RH) (40\%) before and after sampling. A microbalance (AND GH 202, Germany) with a sensitivity of $0.01 \mathrm{mg}$ was used to measure the PM mass collected on the filters. Panalytical Axios Advance model wavelength dispersive X-ray fluorescence (WDXRF) was employed to analyze the samples in terms of sixteen metals including $\mathrm{As}, \mathrm{Cu}, \mathrm{Fe}, \mathrm{Mn}, \mathrm{Pb}, \mathrm{V}$ and $\mathrm{Zn}$. Quality assurance / quality control (QA/QC) of the analysis was closely monitored and reported in Öztürk and Keleş. ${ }^{27}$

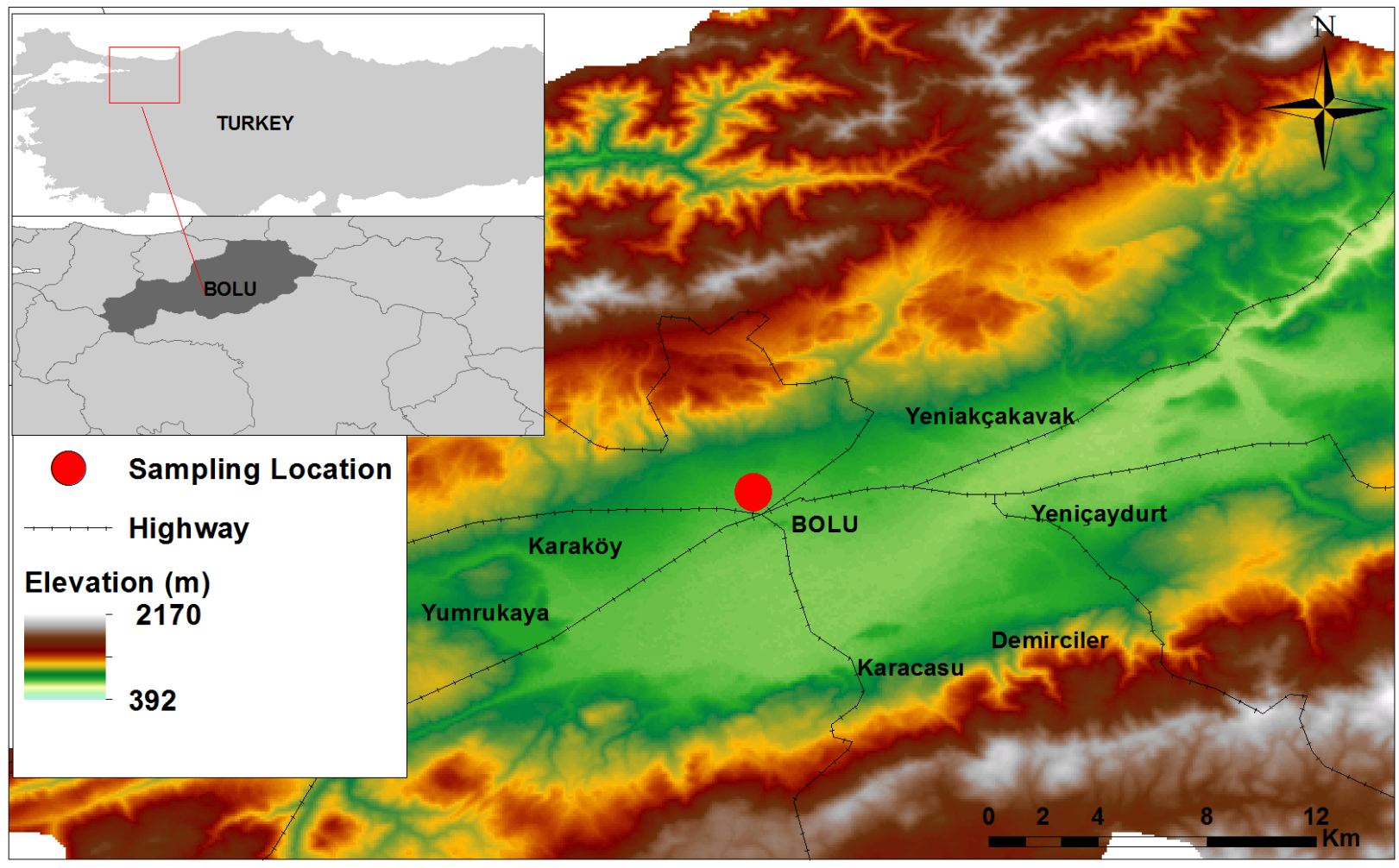

Figure 1. Map of Bolu showing the main highways and sampling station 


\section{Meteorology}

There is a ground-based meteorological station operated by the Turkish State Meteorological Service, which reports to the Ministry of Agriculture and Forestry, at the same site of the sampling point. The meteorological sensor was placed at $10 \mathrm{~m}$ above the ground level. Daily mean temperature, wind speed and direction and relative humidity values interpreted in this study were obtained from this station between 2006 and 2017.

\section{Air Quality Data}

$\mathrm{PM}_{10}$ and $\mathrm{SO}_{2}$ data were monitored continuously at the same site by the Ministry of Environment and Urbanization through the
Air Quality Monitoring Network. The validated daily data for these parameters between 2006 and 2017 were acquired from this network and evaluated herein.

\section{Seasonal Kendall (SK) Test and Sen's Slope Estimation}

In order to find the long-term changes in monitored air quality parameters $\left(\mathrm{PM}_{10}\right.$ and $\mathrm{SO}_{2}$, in this case), the SK test and Sen's slope estimator were applied as non-parametric methods. The SK test is unaffected by the presence of cycles. ${ }^{28}$ Moreover, it can be applied to data with missing values and ties, which is referred to as equal-valued data. A global trend is meaningful if the trends at all seasons are in the same direction- that is all upward or downward.

The Mann-Kendall statistic $S$ for the data set ' $\mathrm{x}_{\mathrm{i}}$ ' of length ' $\mathrm{n}$ ' is defined in Equation 1:

$$
S=\sum_{k=1}^{n-1} \sum_{j=k+1}^{n} \operatorname{sgn}\left(x_{j}-x_{k}\right)
$$

Where;

$$
\operatorname{sgn}\left(x_{j}-x_{k}\right)=\left\{\begin{array}{lcc}
+1 & \text { if } & \left(x_{j}-x_{k}\right)>0 \\
0 & \text { if } & \left(x_{j}-x_{k}\right)=0 \\
-1 & \text { if } & \left(x_{j}-x_{k}\right)<0
\end{array}\right.
$$

The normal test statistics $\mathrm{Z}$ can be calculated, thereafter, first estimating the var(S) as it was given in Equation 2:

$$
z=\left\{\begin{array}{lll}
\frac{S-1}{\sqrt{\operatorname{Var}(s)}} & \text { if } & S>0 \\
0 & \text { if } & S=0 \\
\frac{S+1}{\sqrt{\operatorname{Var}(s)}} & \text { if } & S<0
\end{array}\right.
$$

A positive value of $\mathrm{Z}$ indicates an increasing trend while negative value reveals a decreasing trend. Either an increasing or decreasing trend (two tailed test) can be 
tested at the 0.05 level of $\alpha$ error, against the null hypothesis, $\mathrm{H}_{0}$, no trend. $\mathrm{H}_{0}$ is rejected if the absolute value of $\mathrm{Z}$ is greater than the $\mathrm{Z}_{1}$ $\alpha / 2$, where $\mathrm{Z}_{1-\alpha / 2}$ is obtained from the standard tables. To determine the global trend, the seasonal trends should be homogenous. To test the homogeneity between the seasons, the
Homogeneity Test originally proposed by Van Belle and Hughes was used in this study. ${ }^{29}$

Finally, the rate of change in the concentration of $\mathrm{SO}_{2}$ and $\mathrm{PM}_{10}$ per time was determined with another non-parametric tool, namely, the Sen's slope estimator, developed by Sen. ${ }^{30}$

In this method, slope estimates of " $n$ " pairs of data are first computed by Equation 3:

$$
Q_{i}=\frac{x_{j}-x_{k}}{j-k} \text { for } i=1 \ldots \ldots n
$$

Where $x_{j}$ and $x_{k}$ are the data values at times $j$ and $k(j>k)$ respectively. Then the median of these $n$ values of $Q_{i}$ is taken as Sen's slope estimator. Afterwards, the median value of $\mathrm{Q}_{\mathrm{i}}$ is tested by a two sided test at the $100(1-\alpha) \%$ confidence interval and the true slope is obtained. ${ }^{31}$

\section{Calculation of Hazard Quotient (HQ) and Cancer Risk (CR)}

In order to address this, the citizens living in the city were classified into the two subgroups as children (0-15 year-old) and adults ( $>15$ year-old) based on difference on their activities and respiratory systems. The main routes of exposure to particulate bound metals were assumed to stem from: (1) dermal absorption of metals on skin (2) inhalation of particle bound metals via mouth and nose and (3) ingestion of deposited particle bound metals. 32,33 The chemical daily intake (CDI) in accordance with the human health evaluation manual (Part A), dermal absorbed dose (DAD) based on the information provided in the supplementary guidance (Part E), and exposure concentration (EC) according to supplementary guidance for inhalation risk assessment (Part F) were calculated utilizing the following Equations (4), (5) and (6): ${ }^{32,34}$

$$
\begin{gathered}
D A D_{\text {dermal }}=\frac{C x S A x A F \times A B S}{B W} \times \frac{E F x E D}{A T} \times C F \\
E C_{\text {inh }}=C x \frac{E T x E F x E D}{A T_{n}} \\
C D I_{\text {ingest }}=\frac{C x \operatorname{Ing} R}{B W} \times \frac{E F x E D}{A T} \times C F
\end{gathered}
$$


where " $\mathrm{C}$ " stands for the 95\% upper confidence limit of the arithmetic mean of the particle bound metal concentrations and can be calculated by using the Equation (7):32

In Equation (7), "X" stands for the arithmetic mean of the log-transformed data, " $s$ " is the standard deviation of the log-transformed data, " $\mathrm{H}$ " is the H-statistic and " $\mathrm{n}$ " is the number of samples in the data set. ${ }^{28}$ Total concentration was used for inhalation and dermal exposure while the concentrations used for ingestion were calculated by using the extractable content of PM as proposed by $\mathrm{Hu}$ et al. in accordance with the simple bioaccessibility extraction test (SBET). ${ }^{32}$

The definitions of the other terms and input parameters used in Equation (4), (5) and (6) are provided in Table 1.

$$
C_{95 \%}=\exp \left\{X+0.5 x s^{2}+\frac{s x H}{\sqrt{n-1}}\right\}
$$

Table 1. Input parameters to characterize the risk assessment

\begin{tabular}{|c|c|c|c|c|}
\hline \multirow[t]{2}{*}{ Parameters $^{\mathbf{a}}$} & \multirow[t]{2}{*}{ Description } & \multirow[t]{2}{*}{ Unit } & \multicolumn{2}{|c|}{ Value } \\
\hline & & & Adult & Children \\
\hline $\mathrm{C}$ & Metal Concentration in PM & $\mu \mathrm{g} / \mathrm{m}^{3}$ & & \\
\hline $\operatorname{IngR}$ & Ingestion rate & mg/day & 100 & 200 \\
\hline $\mathrm{EF}$ & Exposure frequency & day/year & 180 & 180 \\
\hline ED & Exposure duration & years & 24 & 6 \\
\hline ET & Exposure time & hours/day & 24 & 24 \\
\hline SA & Skin area & $\mathrm{cm}^{2}$ & 3300 & 2800 \\
\hline $\mathrm{AF}$ & Skin adherence factor & $\mathrm{mg} / \mathrm{cm}^{2} / \mathrm{h}$ & 0.07 & 0.2 \\
\hline \multirow[t]{3}{*}{ ABS } & Dermal absorption factor & & 0.001 & 0.001 \\
\hline & - As & & 0.03 & 0.03 \\
\hline & - Others & & 0.01 & 0.01 \\
\hline $\mathrm{CF}$ & Conversion factor & $\mathrm{kg} / \mathrm{mg}$ & 0.000001 & 0.000001 \\
\hline BW & Average Body Weight & $\mathrm{kg}$ & 70 & 15 \\
\hline \multirow[t]{3}{*}{ AT } & Averaging time & hours & & \\
\hline & - Carcinogens & & $70 \times 365$ & $70 \times 365$ \\
\hline & - Non-carcinogens & & EDx365 & EDx365 \\
\hline \multirow[t]{3}{*}{$\mathrm{AT}_{\mathrm{n}}$} & Averaging time & hours & & \\
\hline & - Carcinogens & & $70 \times 365 \times 24$ & $70 \times 365 \times 24$ \\
\hline & - Non-carcinogens & & EDx365x24 & EDx365x24 \\
\hline
\end{tabular}


All the values in Table 1 were provided in $\mathrm{Hu}$ et al. except for the skin adherence factor for adults, which was taken from Cheng et al.32,35 Although head and hands of the exposed population are naked during exposure, the total surface area of these parts of the body is only $10 \%$ of the total body surface area. ${ }^{36}$ In the calculation of dermal exposure, it is assumed in this study that whole body surface area is exposed to PM related pollution.

The non-carcinogenic and carcinogenic risks for inhabitants due to each particle bound metal were estimated using Equation (8) and (9). ${ }^{32-34}$ Hazard quotient (HQ) was used to evaluate non-carcinogenic risks, while carcinogenic risk (CR) value was estimated to interpret detrimental risk for inhabitants exposed to airborne metals. Equation 10 was used to calculate Hazard Index (HI), which is equal to the sum of $\mathrm{HQ}$ for metals and exposure pathways of concern in this study. This summation assumes that the health effects of the various PM bound metals, to which a receptor is exposed, are additive.$^{37}$ Total Cancer Risk (TR), which is the sum of CR values for three exposure pathways considered in this study, calculated by using Equation 11.

$$
\begin{gathered}
H Q=\frac{C D I}{R f D_{0}}=\frac{D A D}{R f D_{0} x G I A B S}=\frac{E C}{R f C_{i} x 1000 \mu g g^{-1}} \\
C R=C D I x S F_{0}=D A D x\left(\frac{S F_{0}}{G I A B S}\right)=I U R x E C \\
H I=\sum H Q_{i} \\
T R=\sum C R_{i}
\end{gathered}
$$

Where $\mathrm{RfD}_{0}$ stands for oral reference dose (mg/kg/day); $\quad \mathrm{RfC}_{\mathrm{i}}$ denotes inhalation reference concentrations $\left(\mathrm{mg} / \mathrm{m}^{3}\right) ; \mathrm{SF}_{0}$ is oral slope factor ((mg/kg/day) $\left.{ }^{-1}\right)$; GIABS stands for gastrointestinal absorption factor; IUR is inhalation unit risk $\left.\left(\left(\mu \mathrm{g} / \mathrm{m}^{3}\right)\right)^{-1}\right)$. The $\mathrm{RfD}_{0}$, $\mathrm{RfC}_{\mathrm{i}}, \mathrm{SF}_{0}$, GIABS and IUR were obtained from US EPA website. ${ }^{34}$ The related variables and assumptions used for the calculation of HQ and CR are summarized in Table 2. The approach of using $\mathrm{SF}_{0}$ is based on two assumptions: (1) There are no exposures that have no risk, which implies that even a very low exposure to a cancer leading pollutant increase cancer risk, (2) There is a linear relationship between dose of pollutant and response. ${ }^{38}$ The HQ was calculated for $\mathrm{V}, \mathrm{Mn}$ (diet), $\mathrm{Fe}, \mathrm{Cu}, \mathrm{Zn}$ (metallic), As (inorganic) and $\mathrm{Pb}$ (acetate) while CR was estimated only for As (inorganic) and $\mathrm{Pb}$ (acetate) since $\mathrm{SF}_{0}$ and IUR data was just provided for these parameters in. ${ }^{39}$ Lead (II) acetate is highly soluble salt of $\mathrm{Pb}$ in water and hence, it is more readily bio-accessible form of $\mathrm{Pb}$, which explains why this form of $\mathrm{Pb}$ is suggested to use in the human exposure studies. ${ }^{40}$ 
Table 2. Variables and assumptions used for calculation of HQ and CR

\begin{tabular}{|c|c|c|c|c|c|c|}
\hline Parametera & $\mathrm{RfD}_{0}$ & $\mathbf{R f C}_{\mathbf{i}}$ & GIABS & $\mathbf{S F}_{0}$ & IUR & $\begin{array}{c}\text { SBET } \\
\text { extractable } \\
\text { content }\end{array}$ \\
\hline & (mg/kg-day) & $\left(\mathrm{mg} / \mathrm{m}^{3}\right)$ & & $\begin{array}{c}\text { (mg/kg- } \\
\text { day) }\end{array}$ & $\left(\mu \mathrm{g} / \mathrm{m}^{3}\right)^{-1}$ & $(\%)$ \\
\hline V & 0.005 & 0.0001 & 0.026 & & & 11.2 \\
\hline Mn (Diet) & 0.14 & 0.00005 & 1 & & & 47.6 \\
\hline $\mathrm{Fe}$ & 0.7 & 1 & 1 & & & 3.88 \\
\hline $\mathrm{Cu}$ & 0.04 & & 1 & & & 29.8 \\
\hline Zn (Metallic) & 0.3 & & 1 & & & 60.1 \\
\hline As (Inorganic) & 0.0003 & 0.000015 & 1 & 1.5 & 0.0043 & 38.8 \\
\hline $\mathrm{Pb}$ (acetate) & 0.0035 & & 1 & 0.28 & 0.00008 & 47 \\
\hline
\end{tabular}

HI above unity or below unity indicates the important or non important risk of noncarcinogenic impacts, respectively. ${ }^{32,33}$ The acceptable limit for $\mathrm{CR}$, defined as the probability of an individual developing any sort of cancer from lifetime exposure to carcinogenic hazards suffering from any type of, is assumed to range from $1 \times 10^{-6}$ to $1 \times 10^{-4}$ for regulatory purposes. ${ }^{34}$

\section{Results}

Data Description

Descriptive statistics for air quality parameters $\left(\mathrm{PM}_{10}\right.$ and $\left.\mathrm{SO}_{2}\right)$ and meteorological parameters including temperature and relative humidity (RH) between 2006 and 2017 for the sampling location are provided in Table 3 . As it can be seen from Table 3 that the average $\mathrm{SO}_{2}$ concentration was measured at $43.1 \pm 68.6$ $\mu \mathrm{g} / \mathrm{m}^{3}$ while that for $\mathrm{PM}_{10}$ was $79.9 \pm 76.0$ $\mu \mathrm{g} / \mathrm{m}^{3}$ for the period. The $\mathrm{RH}$ was noticed to vary from 31.9 to $99.5 \%$ with a mean value of $74 \%$ between 2006 and 2017. The mean wind speed was measured as $1.39 \mathrm{~m} / \mathrm{s}$ while its minimum and maximum were observed at 0.4 and $3.6 \mathrm{~m} / \mathrm{s}$, respectively. The dominant wind direction was $186.3^{\circ}$ at the sampling site between 2006 and 2017. 
Table 3. Summary statistics of pollutants and meteorological parameters for Bolu city center between 2006 and 2017

\begin{tabular}{|c|c|c|c|c|c|c|c|}
\hline Variable & Mean & SD & Median & $\begin{array}{c}25^{\text {th }} \\
\text { Percentile }\end{array}$ & $\begin{array}{c}7^{\text {th }} \\
\text { Percentile }\end{array}$ & Min & Max \\
\hline $\mathrm{SO}_{2}\left(\mu \mathrm{g} / \mathrm{m}^{3}\right)$ & 43.1 & 68.6 & 14 & 6 & 46 & 1 & 496 \\
\hline $\mathrm{PM}_{10}\left(\mu \mathrm{g} / \mathrm{m}^{3}\right)$ & 79.9 & 76.0 & 55 & 36 & 93 & 2 & 650 \\
\hline Temperature $\left({ }^{\circ} \mathrm{C}\right)$ & 11.4 & 7.8 & 11.7 & 5.1 & 18.2 & -8.7 & 27.2 \\
\hline $\begin{array}{l}\text { Relative Humidity } \\
(\%)\end{array}$ & 74.0 & 11.5 & 74.3 & 65.9 & 82.4 & 31.9 & 99.5 \\
\hline Wind Speed (m/s) & 1.38 & 0.01 & 1.4 & 1.1 & 1.6 & 0.4 & 3.6 \\
\hline $\begin{array}{l}\text { Wind Direction } \\
\text { (Degree) }\end{array}$ & 186.3 & 1.1 & 195 & 148 & 234 & 1 & 360 \\
\hline
\end{tabular}

\section{Pollution Roses}

Wind speed and direction in relation to urban air quality have been studied for a variety of atmospheric pollutants in the literature. ${ }^{41}$ The increased dispersion in the atmosphere is strongly correlated with the higher wind speeds leading to a drop in pollutant levels and wind direction has local but significant impact on air pollution. ${ }^{42,43}$ The variation of $\mathrm{PM}_{10}$ and $\mathrm{SO}_{2}$ with respect to wind speed and direction in this study was also evaluated and illustrated in Figure 2. The concentration data for these two pollutants was color-coded. It is clear from Figure 2 that both $\mathrm{SO}_{2}$ and $\mathrm{PM}_{10}$ data > $200 \mu \mathrm{g} / \mathrm{m}^{3}$ were observed at wind speeds $<2$ $\mathrm{m} / \mathrm{s}$ reflecting poor atmospheric dispersion conditions. On the other hand, there is no dominant wind direction affecting the measured concentrations at the site, which could be attributed both to the topography of the city and residential heating as the main source of pollution. 


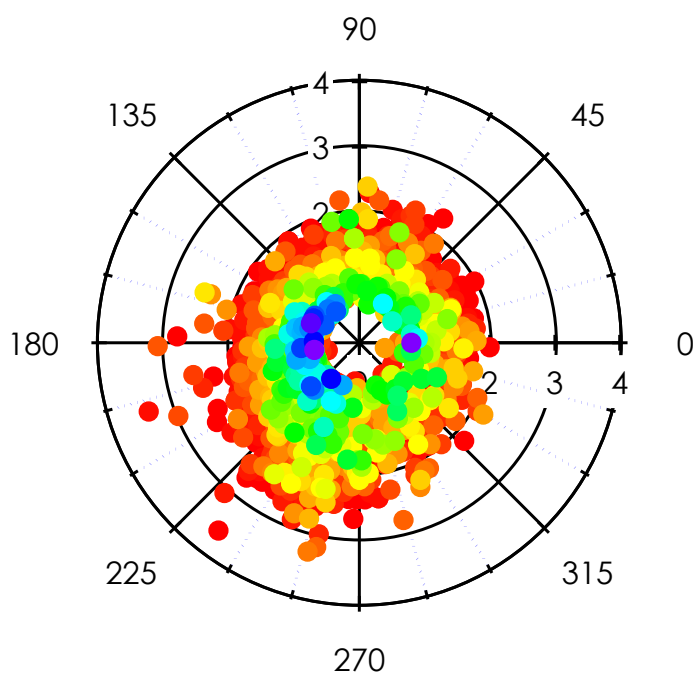

$\mathrm{SO}_{2}$ Concentration $\left(\mu \mathrm{g} / \mathrm{m}^{3}\right)$
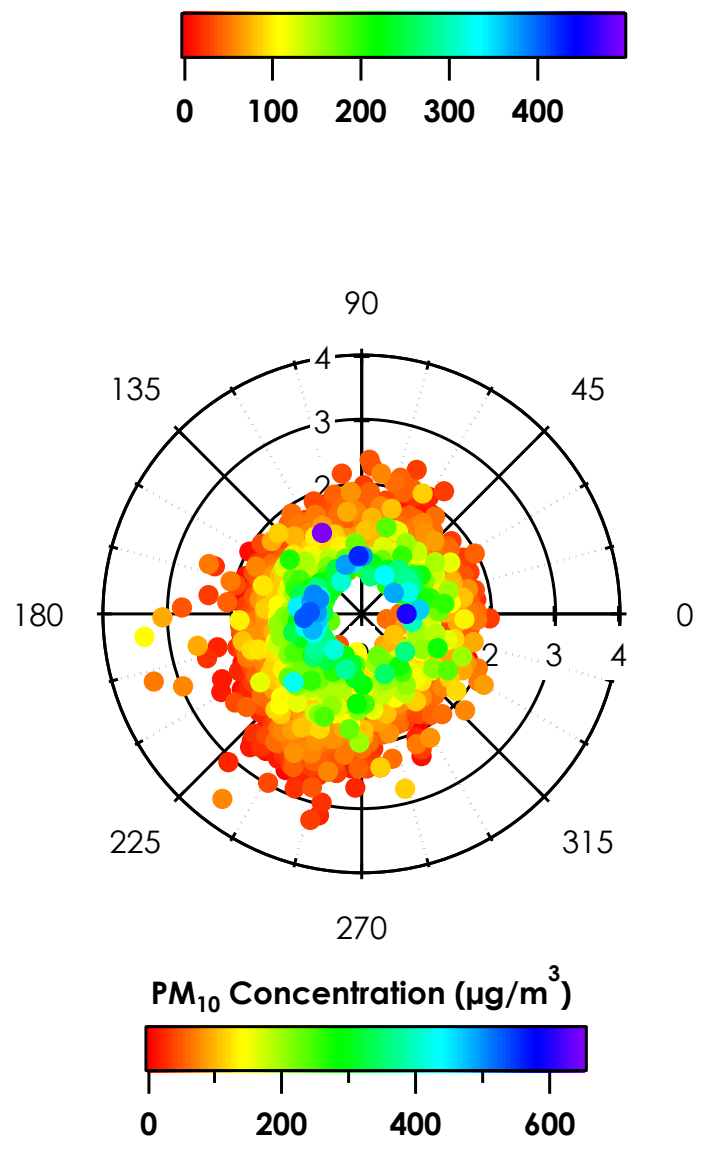

Figure 2. Variation of $\mathrm{SO}_{2}$ (upper panel) and $\mathrm{PM}_{10}$ (lower panel) with respect to wind direction and speed 
Temporal Variation of Air Quality and Meteorological Parameters

Temporal variation of the air quality and meteorological parameters were also assessed in this study and results were depicted in Figure 3 between 2006 and 2017 for Bolu city center. Thirty-day smoothed means were also calculated for air quality and meteorological parameters and shown with the red line on Figure 3.
Figure 4 depicts the annual variations of $\mathrm{PM}_{10}$ and $\mathrm{SO}_{2}$ between 2006 and 2017 as box-whisker plots. SK test was also performed to find whether there was a statistically significant decrease in the measured concentrations of these parameters and to calculate the magnitude of this trend if it exists. For both of the parameters, statistically significant decreasing trend was detected at a $5 \%$ significance level.

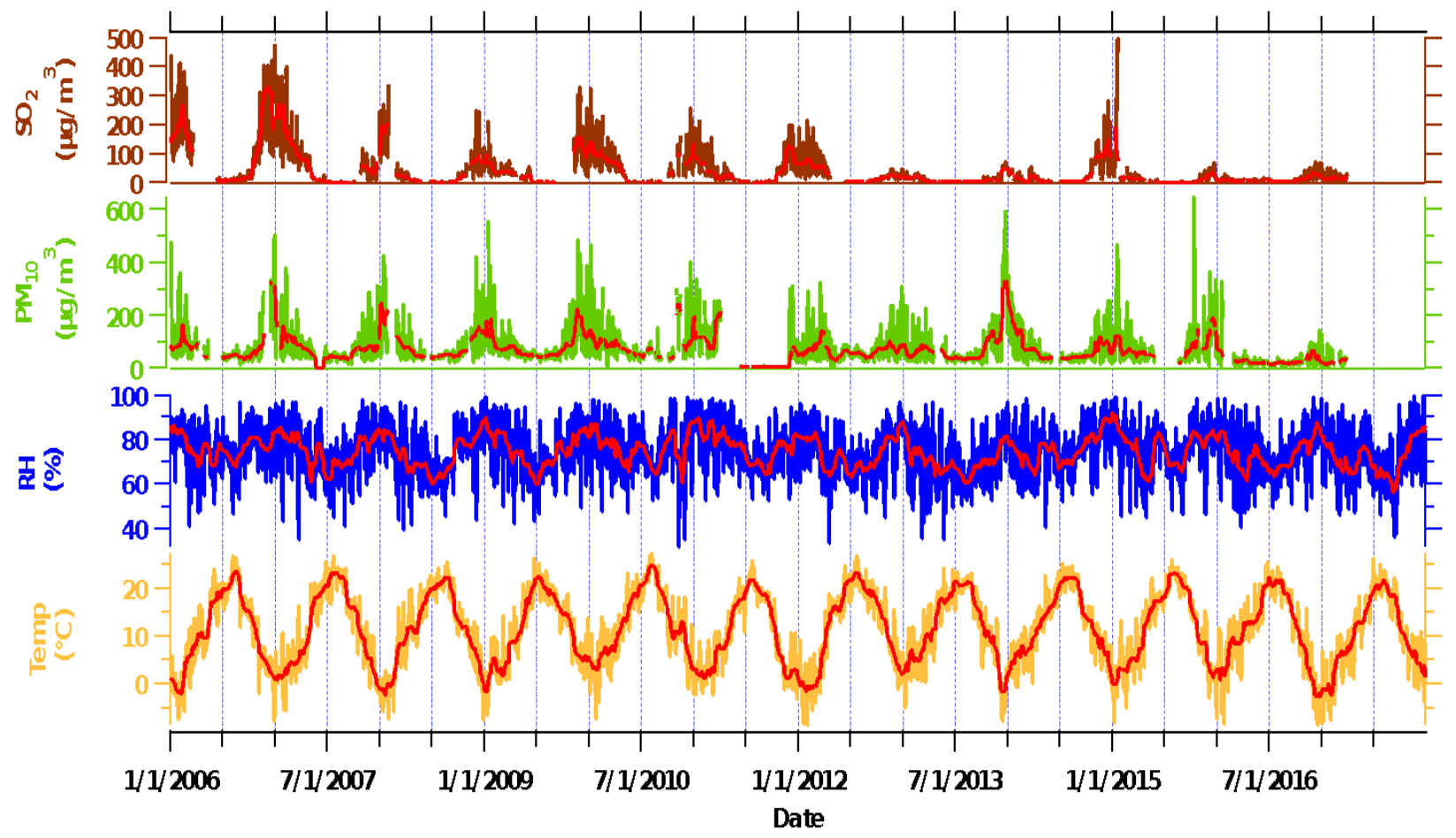

Figure 3. Long term variation of meteorological and air quality parameters (red line shows the smoothed median for each parameter) 

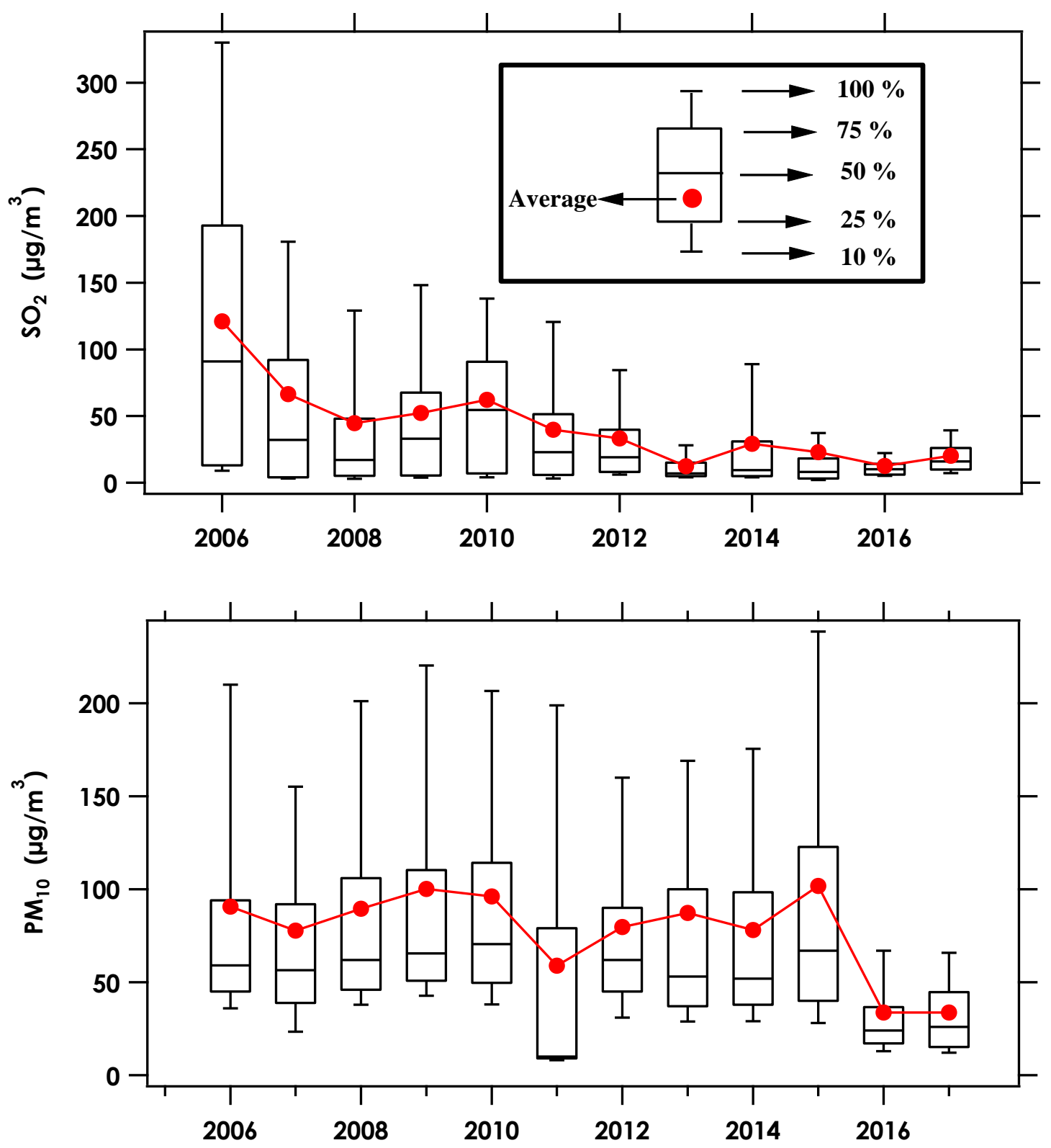

Figure 4. Annual variations of $\mathrm{SO}_{2}$ (upper panel) and $\mathrm{PM}_{10}$ (lower panel) between 2006 and 2017

Monthly variation of $\mathrm{SO}_{2}, \mathrm{PM}_{10}$ and temperature data was depicted in Figure 5. The mean and one standard deviation for each parameter were illustrated in Figure 5. The monthly mean RH data was around $80 \%$ for all months and showed little variation among the months. For this reason, it was not displayed in Figure 5. The highest temperature was recorded in August as $21.4 \pm 2.3^{\circ} \mathrm{C}$ while the lowest value for this parameter was measured in January as $1.2 \pm 4.3^{\circ} \mathrm{C}$. Maximum and minimum monthly mean concentrations for $\mathrm{SO}_{2}$ was observed in January and August as $106 \pm 119$ and $5.5 \pm 4.4 \mu \mathrm{g} / \mathrm{m}^{3}$, respectively. Similar to $\mathrm{SO}_{2}, \mathrm{PM}_{10}$ also showed very pronounced monthly variation as depicted in Figure 5. 


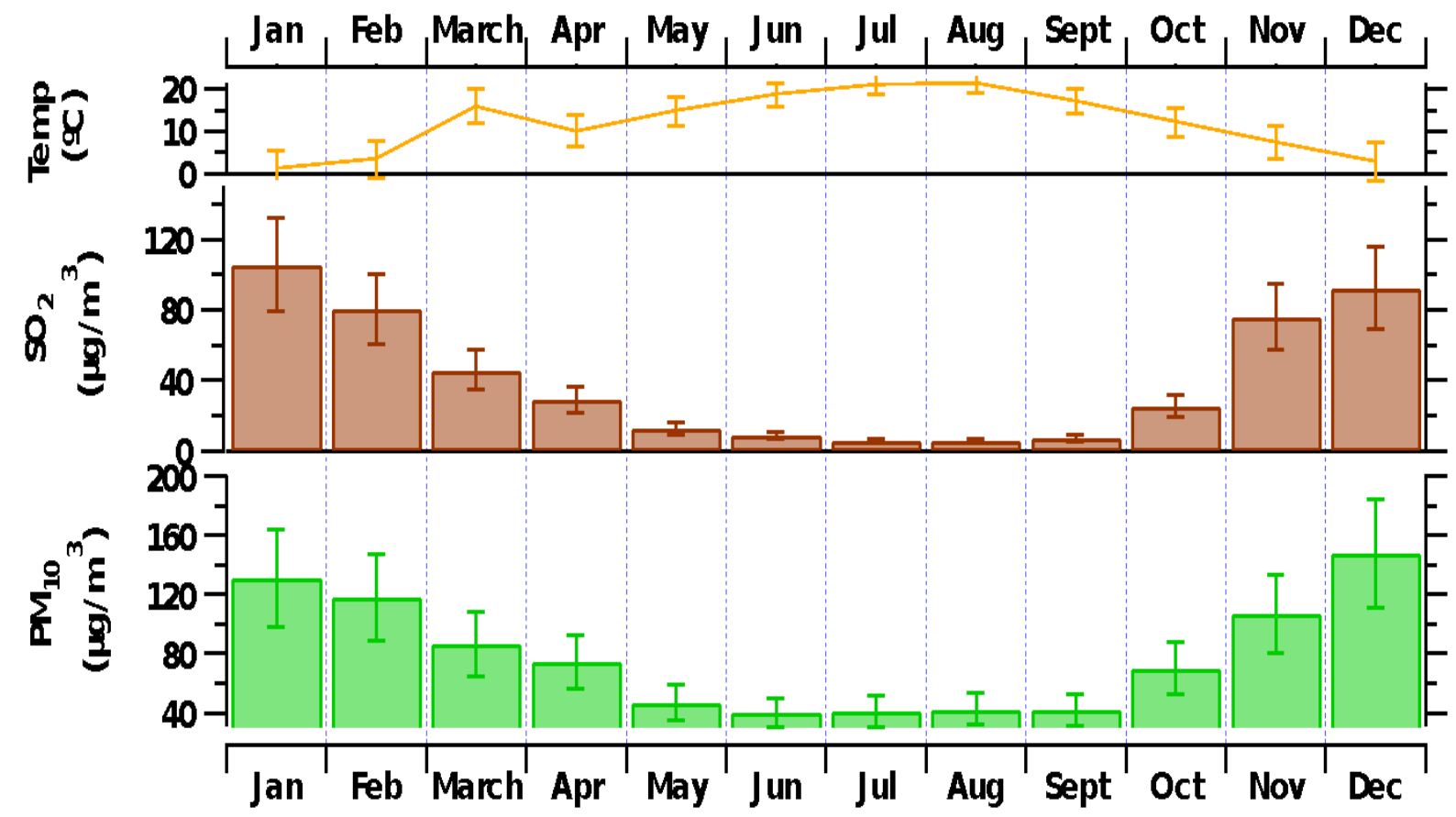

Figure 5. Monthly variations of temperature and air quality parameters

\section{Exposure Risk Assessment}

As stated previously, one of the major objectives of this study was to explore the impacts of metals determined in fine and coarse fraction of PM on human health during wintertime, when the levels of air pollutants elevated due to stable atmospheric conditions. The non-carcinogenic risks from metals $(\mathrm{V}$, $\mathrm{Mn}, \mathrm{Fe}, \mathrm{Cu}, \mathrm{Zn}, \mathrm{As}$ and $\mathrm{Pb}$ ) were calculated and listed in Table 4. Table 4 shows not only HQ values calculated for $\mathrm{As}, \mathrm{Cu}, \mathrm{Fe}, \mathrm{Mn}, \mathrm{Pb}, \mathrm{V}$ and $\mathrm{Zn}$ measured in the coarse and fine PM fractions for adults and children, but also the calculated $\mathrm{HI}$ values presented in bold and italics.

The $\mathrm{CR}$ values due to $\mathrm{As}$ and $\mathrm{Pb}$ measured in $\mathrm{PM}_{2.5-10}$ and $\mathrm{PM}_{2.5}$ are listed in Table 5 for children and adults. 
Table 4. Non-carcinogenic risk for children and adults exposed to $\mathrm{PM}_{2.5-10}$ and $\mathrm{PM}_{2.5}$ PM2.5-10 Hazard Quotient (HQ) Risk

\begin{tabular}{|c|c|c|c|c|c|c|c|c|}
\hline & \multicolumn{4}{|c|}{ Children } & \multicolumn{4}{|c|}{ Adult } \\
\hline & Ingestion & Dermal & Inhalation & Sum & Ingestion & Dermal & Inhalation & Sum \\
\hline V & $8.60 \mathrm{E}-04$ & $1.98 \mathrm{E}-01$ & $6.56 \mathrm{E}-03$ & $2.06 E-01$ & $9.21 \mathrm{E}-05$ & $1.75 \mathrm{E}-02$ & $6.56 \mathrm{E}-03$ & $2.42 E-02$ \\
\hline Mn & $5.12 \mathrm{E}-04$ & $7.23 \mathrm{E}-04$ & $3.04 \mathrm{E}-02$ & $3.16 E-02$ & $5.49 \mathrm{E}-05$ & $6.39 \mathrm{E}-05$ & 3.04E-02 & $3.05 E-02$ \\
\hline $\mathbf{F e}$ & $2.04 \mathrm{E}-05$ & $3.53 \mathrm{E}-04$ & $6.47 \mathrm{E}-06$ & $3.80 E-04$ & $2.18 \mathrm{E}-06$ & $3.12 \mathrm{E}-05$ & $6.47 \mathrm{E}-06$ & $3.99 E-05$ \\
\hline $\mathrm{Cu}$ & $5.73 \mathrm{E}-04$ & $1.29 \mathrm{E}-03$ & & $1.87 E-03$ & $6.14 \mathrm{E}-05$ & $1.14 \mathrm{E}-04$ & & $1.76 E-04$ \\
\hline Zn & $2.60 \mathrm{E}-04$ & $2.91 \mathrm{E}-04$ & & $5.52 E-04$ & $2.79 \mathrm{E}-05$ & $2.57 \mathrm{E}-05$ & & $5.37 E-05$ \\
\hline As & $4.54 \mathrm{E}-02$ & $2.36 \mathrm{E}-01$ & $3.31 \mathrm{E}-02$ & $3.14 E-01$ & $4.86 \mathrm{E}-03$ & $2.08 \mathrm{E}-02$ & $3.31 \mathrm{E}-02$ & $5.88 E-02$ \\
\hline $\mathbf{P b}$ & $1.75 \mathrm{E}-02$ & $2.50 \mathrm{E}-02$ & & $4.25 E-02$ & $1.87 \mathrm{E}-03$ & $2.21 \mathrm{E}-03$ & & $4.08 E-03$ \\
\hline Sum & $6.51 E-02$ & $4.62 E-01$ & $7.01 E-02$ & $5.97 E-01$ & $6.97 E-03$ & $\begin{array}{l}4.08 E- \\
02\end{array}$ & $7.01 E-02$ & $1.18 E-01$ \\
\hline \multicolumn{9}{|c|}{ PM$_{2.5}$ Hazard Quotient (HQ) Risk } \\
\hline & \multicolumn{4}{|c|}{ Children } & \multicolumn{4}{|c|}{ Adult } \\
\hline & Ingestion & Dermal & Inhalation & Sum & Ingestion & Dermal & Inhalation & Sum \\
\hline V & $1.08 \mathrm{E}-03$ & 2.49E-01 & $4.68 \mathrm{E}-03$ & $2.55 E-01$ & $1.16 \mathrm{E}-04$ & $2.21 \mathrm{E}-02$ & $4.68 \mathrm{E}-03$ & $2.68 E-02$ \\
\hline Mn & $4.71 \mathrm{E}-04$ & $6.65 \mathrm{E}-04$ & $3.23 \mathrm{E}-02$ & $3.34 E-02$ & $5.05 \mathrm{E}-05$ & $5.88 \mathrm{E}-05$ & 3.23E-02 & $3.24 E-02$ \\
\hline $\mathbf{F e}$ & $1.97 \mathrm{E}-05$ & $3.40 \mathrm{E}-04$ & $5.34 \mathrm{E}-06$ & $3.65 E-04$ & $2.11 \mathrm{E}-06$ & $3.01 \mathrm{E}-05$ & $5.34 \mathrm{E}-06$ & $3.75 E-05$ \\
\hline $\mathbf{C u}$ & $8.26 \mathrm{E}-04$ & $1.86 \mathrm{E}-03$ & & $2.69 E-03$ & 8.85E-05 & $1.65 \mathrm{E}-04$ & & $2.53 E-04$ \\
\hline $\mathbf{Z n}$ & $2.93 \mathrm{E}-04$ & $3.27 \mathrm{E}-04$ & & $6.20 E-04$ & $3.14 \mathrm{E}-05$ & 2.89E-05 & & $6.03 E-05$ \\
\hline As & $3.85 \mathrm{E}-02$ & $2.00 \mathrm{E}-01$ & $3.33 \mathrm{E}-02$ & $2.72 E-01$ & $4.12 \mathrm{E}-03$ & $1.77 \mathrm{E}-02$ & 3.33E-02 & $5.50 E-02$ \\
\hline $\mathbf{P b}$ & $1.69 \mathrm{E}-02$ & $2.41 \mathrm{E}-02$ & & $4.10 E-02$ & $1.81 \mathrm{E}-03$ & $2.13 \mathrm{E}-03$ & & $3.94 E-03$ \\
\hline Sum & $5.80 E-02$ & $4.77 E-01$ & $7.02 E-02$ & $6.05 E-01$ & $6.22 E-03$ & $\begin{array}{l}4.21 E- \\
02\end{array}$ & $7.02 E-02$ & $1.19 E-01$ \\
\hline
\end{tabular}

Table 5 Carcinogenic risk for children and adults exposed to $\mathrm{PM}_{2.5-10}$ and $\mathrm{PM}_{2.5}$

\begin{tabular}{|c|c|c|c|c|c|c|c|c|}
\hline \multicolumn{9}{|c|}{$\mathbf{P M}_{2.5-10}$ Carcinogenic Risk (CR) } \\
\hline & \multicolumn{4}{|c|}{ Children } & \multicolumn{4}{|c|}{ Adult } \\
\hline & Ingestion & Dermal & Inhalation & Sum & Ingestion & Dermal & Inhalation & Sum \\
\hline As & $1.75 \mathrm{E}-06$ & $9.09 \mathrm{E}-06$ & $1.83 \mathrm{E}-07$ & 1.10E-05 & $7.50 \mathrm{E}-07$ & $3.21 \mathrm{E}-06$ & $7.32 \mathrm{E}-07$ & $4.70 E-06$ \\
\hline $\mathbf{P b}$ & $1.47 \mathrm{E}-06$ & $2.10 \mathrm{E}-06$ & $1.22 \mathrm{E}-08$ & $3.58 E-06$ & $6.30 \mathrm{E}-07$ & 7.43E-07 & $4.88 \mathrm{E}-08$ & $1.42 E-06$ \\
\hline Sum & $3.22 E-06$ & $1.12 E-05$ & $1.95 E-07$ & $1.46 E-05$ & $1.38 E-06$ & $3.96 E-06$ & $7.81 E-07$ & $6.12 E-06$ \\
\hline \multicolumn{9}{|c|}{ PM2.5 Carcinogenic Risk (CR) } \\
\hline & \multicolumn{4}{|c|}{ Children } & \multicolumn{4}{|c|}{ Adult } \\
\hline & Ingestion & Dermal & Inhalation & Sum & Ingestion & Dermal & Inhalation & Sum \\
\hline$\overline{\text { As }}$ & $1.48 \mathrm{E}-06$ & $7.71 \mathrm{E}-06$ & $1.84 \mathrm{E}-07$ & $9.37 E-06$ & $6.36 \mathrm{E}-07$ & $2.72 \mathrm{E}-06$ & $7.36 \mathrm{E}-07$ & $4.09599 E-06$ \\
\hline $\mathbf{P b}$ & $1.42 \mathrm{E}-06$ & $2.03 \mathrm{E}-06$ & $1.14 \mathrm{E}-08$ & $3.45 E-06$ & $6.07 \mathrm{E}-07$ & $7.16 \mathrm{E}-07$ & $4.57 \mathrm{E}-08$ & $1.36901 E-06$ \\
\hline Sum & $2.90 E-06$ & $9.73 E-06$ & $1.95 E-07$ & $1.28 E-05$ & $1.24 E-06$ & $3.44 E-06$ & $7.81 E-07$ & $5.465 E-06$ \\
\hline
\end{tabular}




\section{Discussion}

The long term and seasonal variation of criteria pollutants measured in Bolu by the Turkish Ministry of Environment and Urbanization were assessed in this study. Moreover, the health impacts of metals bound to coarse and fine fraction of PM were evaluated.

Once the measured daily average $\mathrm{PM}_{10}$ values were compared with the Turkish Air Quality Evaluation and Management Regulation $^{44}$, it was found that about $57 \%$ of time, the threshold value $\left(50 \mu \mathrm{g} / \mathrm{m}^{3}\right)$ set by the regulation was exceeded. Annual mean $\mathrm{PM}_{10}$ concentration data was also observed to exceed $40 \mu \mathrm{g} / \mathrm{m}^{3}$ limit value for all years except for 2015, 2016 and 2017. The daily threshold value for $\mathrm{SO}_{2}\left(125 \mu \mathrm{g} / \mathrm{m}^{3}\right.$, which should not be exceeded more than three times in a year) was also exceeded about $10 \%$ of the time. Prior to 2008, the levels for the ambient air quality parameters were regulated in accordance with the previous version of the regulation, which had been in effect since 1986 . The long-term limit values both for $\mathrm{SO}_{2}$ and $\mathrm{PM}_{10}$ were set to $150 \mu \mathrm{g} / \mathrm{m}^{3}$ while the short-term limit value for $\mathrm{SO}_{2}$ and $\mathrm{PM}_{10}$ were 400 and $300 \mu \mathrm{g} / \mathrm{m}^{3}$, respectively. ${ }^{45}$ The monitored levels for $\mathrm{PM}_{10}$ and $\mathrm{SO}_{2}$ was exceeded the short-term threshold values about $13 \%$ and $7 \%$ of the time, respectively, between 2006 and 2007 according to previous version of the regulation.

In Turkey, the majority of sulfur dioxide $\left(\mathrm{SO}_{2}\right)$ is released to the ambient atmosphere as a result of sulfur containing fuel combustion while industrial processes also emit $\mathrm{SO}_{2}$ to atmosphere to a lesser extent. ${ }^{46}$ There is a pronounced decrease in $\mathrm{SO}_{2}$ concentrations from 2006 to 2017 except for 2015. The reason for this sudden increase in $\mathrm{SO}_{2}$ levels is not clear. One of the major sources that release considerable amount of $\mathrm{SO}_{2}$ to the atmosphere is coal combustion for domestic heating. Though natural gas has been used in the city since 2014, coal combustion is still widespread. Once annual minimum temperature values recorded for the city center was compared during this period, it was seen that corresponding values were close in $2006\left(-8{ }^{\circ} \mathrm{C}\right), 2012\left(-8.6^{\circ} \mathrm{C}\right)$, $2013\left(-7.9^{\circ} \mathrm{C}\right), 2015\left(-8.1^{\circ} \mathrm{C}\right), 2016\left(-8.3^{\circ} \mathrm{C}\right)$ and $2017 \quad\left(-8.7 \quad{ }^{\circ} \mathrm{C}\right)$. Therefore, low temperature values could not alone elucidate the observed trend for $\mathrm{SO}_{2}$ and should be investigated further. In contrast to $\mathrm{SO}_{2}$, there was no obvious decreasing pattern for $\mathrm{PM}_{10}$ levels for Bolu except for 2017.

The associated levels for $\mathrm{SO}_{2}$ and $\mathrm{PM}_{10}$ elevated during winter as temperatures dropped and RH increased whilst pattern in the observed profiles of these pollutants reversed during summer, which reveals the impact of meteorology on the measured concentrations of atmospheric pollutants. Increased use of coal for domestic heating during winter season leads to rise in the levels of these pollutants. The highest $\mathrm{PM}_{10}$ concentration, $156 \pm 106 \mu \mathrm{g} / \mathrm{m}^{3}$, was recorded in January while the lowest one was observed in July as $27.2 \pm 5.6 \mu \mathrm{g} / \mathrm{m}^{3}$. The pattern observed in $\mathrm{SO}_{2}$ and $\mathrm{PM}_{10}$ data reveals that one of the major factors determining the atmospheric levels of pollutants is temperature, which is well published in the literature. ${ }^{47}$ Once the temperature declines during winter (October-March), emissions associated with the coal and biomass combustion for residential heating increase, which partially explains the observed seasonality in the data. Lower atmospheric mixing depth is another reason of the elevated ambient concentrations of pollutants during winter season. Stagnant atmospheric conditions during winter lead to accumulation of atmospheric pollutants while increase of mixing height in summer season results in the dilution of these parameters. Öztürk and Keleş also found elevated concentrations of carbonaceous aerosols at the same site during winter and associated levels were significantly higher than the cited wintertime studies. ${ }^{27}$ Overall it can be concluded that seasonal variation of the pollutants was determined partly by meteorological factors and partly by the heating habits of the residents within the city.

The rate of decrease in $\mathrm{SO}_{2}$ levels was estimated as $1.95 \mu \mathrm{g} / \mathrm{m}^{3} /$ year between 2006 and 2017. Moreover, $\mathrm{PM}_{10}$ concentration dropped with a rate of $2.93 \mu \mathrm{g} / \mathrm{m}^{3} /$ year during this period. Özcan studied the trends of some of the air quality parameters including $\mathrm{SO}_{2}, \mathrm{NO}, \mathrm{NO}_{2}, \mathrm{NO}_{\mathrm{x}}$ and $\mathrm{CO}$ in the ambient air of Istanbul between 2002 and 
$2010 .{ }^{48}$ The researcher found that there was a declining trend in $\mathrm{SO}_{2}$ concentrations for the study period and explained this pattern with the restrictions on the use of high sulfur coal and adoption of natural gas in this mega-city. Ozden et al. assessed the ambient air quality in Eskisehir (Turkey) between 1992 and 2001 in terms of $\mathrm{SO}_{2}$ and $\mathrm{PM} . \mathrm{SO}_{2}$ levels were dropped from $200 \mu \mathrm{g} / \mathrm{m}^{3}$ (1992) to $50 \mu \mathrm{g} / \mathrm{m}^{3}$ (2001) in Eskisehir while PM data stayed around $50 \mu \mathrm{g} / \mathrm{m}^{3}$ between 1992 and $2001 .^{49}$ The researchers attributed the decrease of $\mathrm{SO}_{2}$ to adoption of natural gas in the city starting from 1996. Doğruparmak and Özbay evaluated the long-term variation of atmospheric pollutants including $\mathrm{SO}_{2}$ and $\mathrm{PM}_{10}$ in Kocaeli (Turkey) between 1987 and $2009 .{ }^{50}$ A significant decline in $\mathrm{SO}_{2}$ and $\mathrm{PM}_{10}$ levels was detected for this study after 1995 . This pattern observed in these pollutants was explained by adoption of strict mitigations performed on the usage of smuggled coal in the region.

Wintertime chemical composition of coarse and fine PM was determined in terms of metals in order to evaluate the health risks of citizens under very stable meteorological conditions. The highest HQ was determined for As among the seven metals. The HI values for exposure through dermal contact were 0.462 and 0.041 for children and adults, respectively. These values suggest that children were more prone to noncarcinogenic risks associated with adhesion of metals on the skin. The non-carcinogenic risks associated with the ingestion of particle bound metals in coarse mode were about nine times greater for children than for adults. Exposure to the coarse PM fraction of through inhalation resulted in the same magnitude of the non-carcinogenic risks for both children and adults. The cumulative non-carcinogenic risks due to exposure to the seven metals as determined in $\mathrm{PM}_{2.5-10}$ were not of a major concern for children and adults since the calculated HI values $(0.597$ and 0.118 for children and adults, respectively) were below unity.

Among the measured metals, $\mathrm{V}$ and $\mathrm{As}$ in the fine particle mode were the major air pollutants due to their relatively higher $\mathrm{HI}$ values for children while $\mathrm{Mn}$ in this mode had similar HI value in addition to these two metals for adults. As with the coarse fraction, exposure through inhalation resulted in the same magnitude of the non-carcinogenic risks for both children and adults. The contribution of the non-carcinogenic risks associated with exposure through ingestion to the cumulative risk was about nine times higher for children than for adults, which is due to differences in the ingestion rate assumed for the two population groups. The HI values for exposure through dermal contact were estimated at 0.477 and 0.042 for children and adults, respectively. These values implied that children were more susceptible to the non-carcinogenic risks due to the adhesion of metals on the skin. The cumulative noncarcinogenic risks due to exposure of the seven metals in $\mathrm{PM}_{2.5}$ were not of a major concern for children and adults since their HI values $(0.605$ and 0.119 for children and adults, respectively) were below unity.

The comparison of the cumulative HI values for the coarse and fine particle modes showed that the values of the fine mode were slightly higher than those of the coarse mode for both children and adults. The coarse to fine ratio for the metals was found as 0.88 , $1.00,1.03,1.16,1.46,1.81$, and 2.54 for $\mathrm{Mn}$, $\mathrm{As}, \mathrm{Zn}, \mathrm{Pb}, \mathrm{Cu}, \mathrm{Fe}$ and $\mathrm{V}$, respectively. ${ }^{27}$ Since there is no significant difference in the concentration data used for the performed modelling and log-transformed concentration values were used herein, the estimated $\mathrm{HI}$ values were not considerably different. Hu et al. also reported that exposure via ingestion of airborne metals may lead to potential noncarcinogenic risks to children, while no risk was detected for adults from this exposure route. $^{32}$ Kurt-Karakuş performed a risk assessment using indoor dust data and found that children were nearly two times more susceptible to non-carcinogenic risks than adults due to exposure via a combination of the three routes which was in contrast to our findings. ${ }^{33}$

The CR values of $\mathrm{As}$ and $\mathrm{Pb}$ both in $\mathrm{PM}_{2.5-10}$ and $\mathrm{PM}_{2.5}$ via the combination of dermal contact, ingestion and inhalation were within the acceptable risk tolerable limit $(<$ $1 \times 10^{-4}$ ) for both children and adults. When the $C R$ values were compared for children and adults, adults appeared to be more prone to the carcinogenic risks than children. CR 
values associated with the coarse particle mode were relatively higher than the ones associated with the fine particle mode since slightly higher $\mathrm{As}$ and $\mathrm{Pb}$ concentrations were detected in $\mathrm{PM}_{2.5-10}$ in this study. The coarse to fine ratio for the As and $\mathrm{Pb}$ was found as 1.00 and 1.16, respectively, by Öztürk and Keleș, which is consistent with the findings of Balcılar et al.27,51 Researchers reported considerably higher concentrations of $\mathrm{Pb}$ and As for the coarse mode of the samples, which were collected in the Eastern Black Sea region of Turkey. ${ }^{51}$

It is also worth mentioning here that the exposure duration of the adults was assumed as 24 years in this study. However, residents may spend their whole life (60 to 70 years) in the city, which leads to 2 to 3 times higher cancer risk for them.

\section{Acknowledgement}

The authors gratefully acknowledge the Turkish State Meteorological Service and Turkish Ministry of Environment and Urbanization for providing the meteorological and air quality data, respectively, interpreted in this study.

\section{Conflict of Interest}

Authors declare that they have no conflict of interest.

\section{Financial Support}

Authors have not received any financial support to conduct this study.

\section{Ethics Committee Approval}

This article does not contain any studies with human or animal subjects performed by any of the authors.

\section{References}

1. Kim KH, Lee SB, Woo D, Bae GN. Influence of wind direction and speed on the transport of particle-bound PAHs on a roadway environment. Atmos Pollut Res 2015; 6: 1024-1034.
2. Kelly FJ, Fussell JC. Size, source and chemical composition as determinants of toxicity attributable to ambient particulate matter. Atmos Environ 2012; 60: 504-526.

3. Thurston GD, Burnett RT, Turner MC. et al. Ischemic Heart Disease Mortality and Long-Term Exposure to Source-Related Components of U.S. Fine Particle Air Pollution. Environ Health Perspect 2016; 124(6): 785794.

4. Lim SS, Vos T, Flaxman AD, Danaei G. et al. A comparative risk assessment of burden of disease and injury attributable to 67 risk factors and risk factor clusters in 21 regions, 19902010: a systematic analysis for the Global Burden of Disease Study 2010. Lancet 2012; 380:2224-2260.

5. World Health Organization (WHO), 2014. 7 Million Premature Deaths Annually Linked to Air Pollution. Available at: http://www.who.int/mediacentre/n ews/releases/2014/air-pollution/en. Accessed June 15, 2015.

6. Evans J, van Donkelaar A, Martin RV, Burnett R, Rainham DG, Birkett NJ, Krewski D. Estimates of global mortality attributable to particulate air pollution using satellite imagery. Environ Res 2013; 120:33-42.

7. Samoli E, Analitis A, Touloumi G. et al. Estimating the exposure-response relationships between particulate matter and mortality within the APHEA multicity project. Environ Health Perspect 2005; 113 (1): 88-95.

8. Krewski D, Jerrett M, Burnett RT. et al. Extended follow up and spatial analysis of the American Cancer Society study linking particulate air pollution and mortality. Res Rep Health Eff Inst 2009; 140:5-114 (discussion 115-36).

9. Kloog I, Nordio F, Zanobetti A, Brent AC, Petros K, Joel DS. Short-term effects of particulate exposure on hospital admissions in the Mid- 
Atlantic States: a population estimate. PLOS ONE 2014; 9(2): e88578.

10. Lu F, Xu D, Cheng Y. et al. Systematic review and meta-analysis of the adverse health effects of ambient $\mathrm{PM}_{2.5}$ and $\mathrm{PM}_{10}$ pollution in the Chinese population. Environ Res 2015; 136: 196-204.

11. Pascal M, Falq G, Wagner V. et al. Short-term impacts of particulate matter $\left(\mathrm{PM}_{10}, \mathrm{PM}_{10-2.5}, \mathrm{PM}_{2.5}\right)$ on mortality in nine French cities. Atmos Environ 2014; 95: 175-184.

12. Diociaiuti $M$, Balduzzi $M$, De Berardis B, Cattani G, Stacchini G, Ziemacki G. The two $\mathrm{PM}_{2.5}$ (fine) and $\mathrm{PM}_{2.5-10}$ (coarse) fractions: evidence of different biological activity. Environ Res 2001; 86: 254-262.

13. Gonzalez-Flecha B. Oxidant mechanisms in response to ambient particles. Mol Aspects Med 2004; 25:169-182.

14. Jimenez LA, Thompson J, Brown DA, Rahman I, Antonicell F, Duffin R. Activation of NF-jB by PM $_{10}$ occurs via an iron mediated mechanism in the absence of IjB degradation. Toxicol Appl Pharmacol 2000; 166: 101-110.

15. Burnett RT, Brook J, Dann T. et al. Association between particulate and gas phase components of urban air pollution and daily mortality in eight Canadian cities. Inha Toxicol 2000; 12 (Suppl.4): 15-39.

16. Ostro B, Feng WY, Broadwin R, Green $S$, Lipsett $M$. The effects of components of fine particulate air pollution on mortality in California: results from CALFINE. Environ Health Perspect 2007; 115:13-19.

17. Patel MM, Hoepner L, Garfinkel R. et al. Ambient metals, elemental carbon, and wheeze and cough in New York City children through 24 months of age. Am J Respir Crit Care Med 2009; 180:1107-1113.

18. Bell ML, Ebisu K, Peng RD, Samet JM, Dominici F. Hospital admissions and chemical composition of fine particle air pollution. Am J Respir Crit Care Med 2009; 179: 1115-1120.

19. Hirshon JM, Shardell M, Alles S. et al. Elevated ambient air zinc increases pediatric asthma morbidity. Environ Health Perspect 2008; 116: 826-831.

20. Järup, L. Hazards of heavy metal contamination. Br Med. Bull. 2003; 68(1):167-182.

21. Hellström L, Elinder CG, Dahlberg B. et. al. Cadmium exposure and endstage renal disease. Am J Kidney Dis. 2001; 38:10011-11008.

22. Bellinger DC. Teratogen update: Lead and pregnancy. Birth Defect.Res.Part A Clin Mol Teratol. 2005; 73: 409-420.

23. Shao L, Shi Z, Jones TP, Li J, Whittaker AG, BeruBe KA. Bioreactivity of particulate matter in Beijing air: Results from plasmid DNA assay. Sci Total Environ. 2006; 367:261-272.

24. Pandey JS, Kumar R, Devotta S. Health risks of $\mathrm{NO}_{2}, \mathrm{SPM}$ and $\mathrm{SO}_{2}$ in Delhi (India). Atmos Environ 2005; 39: 6868-6874.

25. Khaniabadi YO, Polosa R, Chuturkova RZ. et al. Human health risk assessment due to ambient $\mathrm{PM}_{10}$ and $\mathrm{SO}_{2}$ by an air quality modeling technique. Process Safety and Environ Protection 2017; 111: 346-354.

26. Kesic MJ, Meyer M, Bauer R, Jaspers I. Exposure to Ozone Modulates Human Airway Protease/Antiprotease Balance Contributing to Increased Influenza A Infection. PLoS ONE 2012; 7(4): e35108.

27. Öztürk F, Keleş M. Wintertime chemical compositions of coarse and fine fractions of particulate matter in Bolu, Turkey. Environ Sci Pollut R 2016; 23(14): 14157-14172.

28. Gilbert RO. Statistical Methods for Environmental Pollution Monitoring. John Wiley \& Sons Inc., ISBN 0-47128878-0, 1987.

29. Van Belle G, Hughes JP. Nonparametric tests for trend in water 
quality. Water Resour Res 1984; 20: 127-136.

30. Sen, PK. Estimates of the regression coefficient based on Kendall's tau. J. Am. Stat. Assoc 1968; 63: 1379-1389.

31. Partal T, Kahya E. Trend analysis in Turkish precipitation data. Hydrol Process 2006; 20: 2011-2026.

32. $\mathrm{Hu} X$, Zhang $Y$, Ding $Z$. et al. Bioaccessibility and health risk of arsenic and heavy metals ( $\mathrm{Cd}, \mathrm{Co}, \mathrm{Cr}$, $\mathrm{Cu}, \mathrm{Ni}, \mathrm{Pb}, \mathrm{Zn}$ and $\mathrm{Mn}$ ) in TSP and $\mathrm{PM}_{2.5}$ in Nanjing, China. Atmos Environ 2012; 57: 146-152.

33. Kurt-Karakus PB. Determination of heavy metals in indoor dust from Istanbul, Turkey: Estimation of the health risk. Environ Int 2012; 50: 4755.

34. US EPA. Risk Assessment Guidance for Superfund. In: Part A: Human Health Evaluation Manual; Part E, Supplemental Guidance for Dermal Risk Assessment; Part F, Supplemental Guidance for Inhalation Risk Assessment. 2011. Available at: vol.I.http://www.epa.gov/oswer/ris kassessment/humal_health_exposure .htm. Accessed August 11, 2015.

35. Cheng Z, Chen LJ, Li $H$. et al. Characteristics and health risk assessment of heavy metals exposure via household dust from urban area in Chengdu, China. Sci Total Environ 2018; 619-620: 621-629.

36. US EPA Dermal Exposure Assessment: Principles and Applications. EPA/600/8-91/011B, 1992.

37. US EPA. Human Health Risk Assessment Protocol for Hazardous Waste Combustion Facilities, EPA530-R-05-006, September 2005.

38. US EPA. Risk Assessment for Toxic Air Pollutants: A Citizen's Guide, EPA 450/3-90-024, March 1991.

39. US EPA Regional Screening Levels Summary Table. 2011. Available at: http://www.epa.gov/region9/superf und/prg/. Accessed August 11, 2015.

40. International Agency for Research on Cancer (IARC). Lead and lead compounds. IARC Monographs on the Evaluation of the Carcinogenic Risk of Chemicals to Humans, Some Metals and Metallic Compounds. IARC, Lyon, France, 1980; 23: 325-415.

41. Jones AM, Harrison RM, Baker J. The wind speed dependence of the concentrations of airborne particulate matter and $\mathrm{NO}_{\mathrm{x}}$. Atmos Environ 2010; 44(13): 1682-1690.

42. Akyüz M, Çabuk H. Meteorological variations of $\mathrm{PM}_{2.5} / \mathrm{PM}_{10}$ concentrations and particle associated polycyclic aromatic hydrocarbons in the atmospheric environment of Zonguldak, Turkey. J Hazard Mater 2009; 170: 13-21.

43. Pateraki $S$, Asimakopoulos DN, Flocas HA, Maggo T, Vasilakos C. The role of meteorology on different sized fractions $\left(\mathrm{PM}_{10}, \mathrm{PM}_{2.5}, \mathrm{PM}_{2.5-10}\right)$. Sci Total Environ 2012: 419, 124-135.

44. Turkish Air Quality Evaluation and Management Regulation (2008). Available at: http://www.mevzuat.gov.tr/Metin.A spx?MevzuatKod=7.5.12188\&Mevzu atIliski=0\&sourceXmlSearch. Accessed May 23, 2018.

45. The Turkish Air Quality Control Regulation (1986). Available at: www.ibb.gov.tr/trTR/kurumsal/.../havakaliteyonetmel ik.doc. Accessed December 1, 2018.

46. Taşdemir Y. Winter season $\mathrm{SO}_{2}$ measurements in Bursa and Comparison with Rural and Urban Area Values. Turkish J Eng Env Sci 2001; 25: 279-287.

47. Zyromski A, Biniak-Pierog M, BursztaAdamiak E, Zamiar Z. Evaluation of relationship between air pollutant concentration and meteorological elements in winter months. J Water Land Dev 2014; 22: 25-32. 
48. Özcan HK. Long Term Variations of the Atmospheric Air Pollutants in Istanbul City. Int J Environ Res Public Health 2012; 9: 781-790.

49. Ozden O, Dogeroglu T, Kara S. Assessment of Ambient Air Quality in Eskisehir, Turkey. Proceedings of the Third International Symposium on Air Quality Management at Urban, Regional and Global Scales; 2005 2630 September; Istanbul, Turkey. 2005. p.200-209.

50. Doğruparmak SÇ, Özbay B. Investigating Correlations and Variations of Air Pollutant Concentrations under Conditions of Rapid Industrialization-Kocaeli (1987-2009). Clean-Soil, Air, Water 2011; 39(7); 597-604.

51. Balcılar I, Zarasız A, Kalaycı Y, Doğan G, Tuncel G. Chemical composition of Eastern Black Sea aerosolPreliminary results. Sci Total Environ 2014; 488-489: 422-428. 